\title{
EXPLORING THE RELATIONSHIP BETWEEN HUMAN RESOURCES MANAGEMENT PRACTICES IN THE HOSPITALITY SECTOR AND SERVICE INNOVATION IN JORDAN: THE MEDIATING ROLE OF HUMAN CAPITAL
}

\author{
Rami MAHMOUD* \\ The University of Jordan, Faculty of Tourism and Hospitality, Department of Hotel Management, Jordan, e-mail: r.mahmoud@ju.edu.jo \\ Ahmad A. AL-MKHADMEH \\ Yarmouk University, Faculty of Tourism and Hotel Management, Department of Hotel Management, Jordan, e-mail: Ahmad.makhdmeh@yu.edo.jo \\ Omar A. ALANANZEH \\ Yarmouk University, Faculty of Tourism and Hotel Management, Department of Hotel Management, Jordan, e-mail: o.ananzeh@yu.edu.jo
}

Ra'ed MASA'DEH

The University of Jordan, Department of Management Information Systems, Jordan, e-mail: r.masadeh@ju.edu.jo

\begin{abstract}
Citation: Mahmoud, R., Al-Mkhadmeh, A.A., Alananzeh, O.A., \& Masa'deh, R. (2021). EXPLORING THE RELATIONSHIP BETWEEN HUMAN RESOURCES MANAGEMENT PRACTICES IN THE HOSPITALITY SECTOR AND SERVICE INNOVATION IN JORDAN: THE MEDIATING ROLE OF HUMAN CAPITAL. GeoJournal of Tourism and Geosites, 35(2), 507-514. https://doi.org/10.30892/gtg.35231-678
\end{abstract}

\begin{abstract}
This study is aimed to explore the relationship between Human Resources Management (HRM) and innovation in services and whether such a relationship is mediated by human capital. The data was gathered from the hospitality sector in Jordan. To evaluate the proposed hypotheses, Structural Equation Modeling (SEM) was used via partial modeling of least squares. The research findings provide clear evidence that the Service Innovation of Jordan's hospitality was positively influenced by HRM activities and human resources. The results show many practical and theoretical effects. Results will help the hospitality sector grow creativity in their services by HRM practices and establish proper use of human capital in their employees through innovation cults. This is one of the few studies that studied the relationship between HRM activities and the sufficient of human capital on hospitality in a developing country, Jordan.
\end{abstract}

Key words: HRM practices, service innovation, hospitality management, Jordan

$* \quad * \quad * \quad * *$

\section{INTRODUCTION}

The tourism and hospitality sector plays a crucial role in any country's economy (Gorochnaya et al., 2021; Akbari and Monzavi, 2015). The tourism industry is one of the most industrial sectors driving the global economy at the present time (Bazazo and Alananzeh, 2020). Many service organizations have recently focused on how to improve their employees' operation, enhance quality services, and increase their market share through encouraging initiatives and innovation activities (Alosani et al., 2020; Chen, 2018; Chen and Peng, 2017). One of the bases on which institutions depend is an investment in innovation because the demand for goods and services is constantly fluctuating and there are horizontal and vertical implications for organizations and changing the patterns of the target market and the economic situation of societies, so the economic returns of innovation exceed the fixed returns in traditional management (Chang and Lee, 2020; Stojcic et al., 2020). The research points out that there are some challenges facing these organizations in providing sufficient human capital that supports innovation activities (Nieves and Agust1, 2016), which negatively reflects the tendency of employees to innovate (Rodríguez-Pose et al., 2020; Waheed et al., 2019). Organizations need innovation in order to survive and prosper (Bonfanti et al., 2018). Innovation is the main factor that shapes performance and leads to competitive advantage (Rodríguez-Pose et al., 2020), in which creativity in products and services are crucial to the rivalry between organizations and competitors (Porter and Stern, 2001). Service Innovation offers a valuable approach to breakthrough change (Anderson et al., 2014), which results in outstanding results (Reynoso et al., 2015).

Despite recognizing the importance and urgent need for innovation in service sector organizations, innovation management in the service sector is little understood (Ardito et al., 2017), and it often fails to produce significant results (Gannon et al., 2015). Where intellectual resources allow workers to take approaches to innovative work (Jaiswal and Dhar, 2015). In order to allow innovation, resources are required to be used in innovation activities (AlMarzouqi, 2019; Buller and McEvoy, 2012), also human resource factors are included too (Ling et al., 2018; Liu et al., 2017). Therefore, the value of creating a community that promotes employees' creative practices is emphasized. Such values will play a role in improving employee habits, which will positively impact their activities and contribute to innovation, where employee behaviors influence service innovation (Kozioł-Nadolna, 2020; Battistelli et al., 2014). Earlier research has acknowledged

\footnotetext{
* Corresponding author
} 
that human capital is a vital resource for realizing a set of capacities on which the distinctive attributes of an organization are focused (Rodríguez-Pose et al., 2020; AlMarzouqi, 2019; Bonfanti et al., 2018). These fundamental issues, in theoretical literature, remain limited, poor, and inadequate in developing countries (Knies and Leisink, 2018), including Arab countries (Kraśnicka et al., 2018; Akbari and Monzavi, 2015), especially in the public sector (Favoreu et al., 2019; Ardito and Messeni, 2017). However, few research has explored the relationship between HRM activities and service innovation. It can therefore be said that this aspect of the service industry investigation remains constrained.

Studies show that HRM activities play a critical role in enhancing the efficiency of companies, increasing their market share, personal initiatives, and service innovation (Ardito and Messeni, 2017; Anderson et al., 2014; Chen and Huang, 2009). Human capital is also one of the most significant factors shaping the success and competitive advantage of companies and service innovation. Studies, however, scarcely concentrate on service innovation and strategies to improve it (AlMarzouqi, 2019). It is also called a burning problem and has the right to address the research void that needs to be addressed. For that, the current study investigates the role of human capital as a mediator in the hospitality of Jordan between HRM practices and service innovation. Several theories have been used in literature to explain the interactions between these variables in hospitality, such as the resource-based view (Waheed et al., 2019), the knowledge-based view (Stojcic et al., 2020), and the theory of human resources (Gannon et al., 2015).

This analysis follows the following measures and procedures in order to achieve this objective. First of all, the study on HRM, human capital, and innovation in services was reviewed. Secondly, the hypotheses were evaluated utilizing quantitative methods involving structure equation modeling (SEM). In this respect, a questionnaire was used to collect data from 280 respondents in Jordan from the hospitality industry. By expanding the current findings of results that comes from the model that describes the relationship between HRM practices and service innovation, the paper will contribute to awareness. Human capital will also make use of the aforementioned partnership as a mediator. In the past, little consideration was paid to the combination of all these variables into a single model. This study is a groundbreaking study that has explored these variables in the hospitality industry. Therefore, it contributes to the body of knowledge by responding to the need to explore the relationship between HRM practices and service innovation, which particularly in the public sector, is characterized as complex and volatile. In addition, the results of the paper will make valuable contributions to the value of Human capital and HRM activities to positively impact service innovation for regulators, managers, and practitioners.

\section{LITERATURE REVIEW}

A significant source of competitive advantage is creativity (Sanz-Valle et al., 2018; Anderson et al., 2014; Dreu et al., 2008). The main drivers of the creativity of organizations have been defined by literature. Recent studies have highlighted the role of human resources in creating creativity and the value of creating new services. The main channels by which organizations can influence their human resources are HRM activities. The influence of HRM practices on service innovation has been examined in several studies (Alosani et al., 2020; Chen, 2018; Ardito et al., 2017; Bamber et al., 2017; Engelman et al., 2017; Escriboa-Carda et al., 2017; Chang et al., 2011) and the direct relation between HRM practices and service innovation (Waheed et al., 2019; Ardito and Messeni, 2017; Akbari and Monzavi, 2015). Research on this subject, however, remains immature (Tajeddini et al., 2020; Ardito et al., 2017) and empirical studies focusing on this subject remain scarce (Bonfanti et al., 2018; Losey, 2012) in the government sector in particular (AlMarzouqi, 2019; Battistelli et al., 2014). Studies have stressed the need for such organizations to investigate this relationship (Stojcic et al., 2020; Carmeli and Schaubroeck, 2013), given the lack of academic attention (Chang and Lee, 2020) and the weak interest of government organizations in this subject (Carmeli and Schaubroeck, 2013). In addition, studies have suggested conducting research on service innovation in various countries and different service industries (Bonfanti et al., 2018).

\section{Service Innovation}

Innovation is a new method of producing new products. In service industry, innovation refers to the process of significant improvement in goods or services and how they are marketed and organized inside or outside the organization (Ganzer et al., 217). It is the creation of new products, processes, and services, resulting in substantial improvements in the effectiveness, competence, regions' development, and quality of services (Ebersberger et al., 2021; Trusova et al., 2020; Mulgan and Albury, 2003). Alosani et al. (2019), however, argued that this definition of the innovation of an organization still needs to be extended by other factors related to HR. The organization's human resources reflect the knowledge base that can influence innovation and achieve success (Bonfanti et al., 2018); therefore, the culture of innovation is highly linked to HRM for the attraction and retention of talent (Ardito et al., 2017). Various authors have various conceptualizations of creativity in operation.

Some writers approached it from the point of view of market development systems, while others addressed it from the perspective of resource growth and culture (Chang and Lee, 2020; Booyens and Rogerson, 2016). It was presented by some from positive and interactive perspectives (Akbari and Monzavi, 2015). The development of the value of services is carried out by interactive innovation, according to Salunke et al. (2013), whereas supportive innovation implies indirect value generated at the back end to help a new value proposition. Along these lines, Akbari and Monzavi (2015) argued, classifying service innovation into process innovation, service product modifications, architectural innovation, and product innovation. Buller and McEvoy (2012) indicated that innovation in services contributes to the enhancement of systems and services by improvements in the business theater. Chang et al. (2011) concluded that service innovation requires not just the improvement of new service products and processes, but also the adoption of them by target customers.

Service innovation is, therefore, defined as developing new or enhancing existing services and processes for the purposes of this report. Innovation is very critical in building public organizations' credibility and reputation, as people tend to assume 
that hospitality sector services tend to be less quality-based than private service providers. With service innovation in the hospitality industry, there are substantial opportunities to increase the quality of services offered, boost economic growth, and draw more investors (Gorochnaya et al., 2021; Favoreu et al., 2019; Waheed et al., 2019).

\section{Human Resource Management Practices}

The Department of Human Management is the backbone of managing institutions, especially service industries, as the implementation of this section includes techniques and procedures for the effective implementation of its human resource management policies (Deeb et al., 2020; Boxal et al., 2007). This description is consistent with Wright et al. (1999), who describes HRM practices as organizational activities aimed at managing the human capital pool and ensuring that capital is used to achieve organizational objectives. They explain that the activities of human resources management are the procedures through which organizations can effectively exploit the ability of employees and provide them with opportunities for creativity. HRM practices is the key component of development and growth, it supports organizations in their decision-making, teamwork, empowerment, collaboration (Alosani et al., 2020), and organizational trust (Chang and Lee, 2020; Chivandi and Maziriri, 2018). This issue will be positively reflected in the promotion of knowledge and employee awareness behaviors, which in turn lead to improving their capacity to innovate (Favoreu et al., 2019). Nevertheless, despite studies examining the importance of HRM procedures and policies in innovation, these contributions remain minimal and poor in theory and empirical evidence. Furthermore, little study has explored how HRM activities impact creativity in the hospitality sector (Favoreu et al., 2019; Chowhan, 2016). Therefore, this portion of the hospitality sector survey remains small.

\section{Human Capital}

Human capital refers to the collection of expertise, abilities, and skills embedded in the human resources of the company' (Lepak and Snell, 2002). The connection with human behavior is one basic element of awareness. Thus, information production would be intrinsically related to the number of human resources in the organization. People with high levels of expertise, skills, and experience, on the one hand, are a source of innovative ideas for organizations. Organizations will find a wide variety of expertise in these types of workers, greater versatility in learning new information, and increased capacity to challenge existing organizational expectations and build new methods of thinking (Bonfanti et al., 2018; Subramaniam and Youndt, 2005). Human capital is one of the most significant factors affecting innovation (Bonfanti et al., 2018; Nieves and Agust1, 2016; Yamao et al., 2009; Subramaniam and Youndt, 2005) and is one of the key pillars of the functioning of a company (Yang and Lin, 2009). A company that incorporates technology into its human capital is more likely to achieve its goals (Elsharnouby and Elbanna, 2021; Nieves and Agust1, 2016; Salem, 2014).

It can also be said that human capital is mean to handling creativity in the enterprise since it produces new ideas (Nieves and Agust1, 2016). As a consequence, the greater the Human capital stock, the greater the possibilities for these forms of information sharing and combination processes to take place (Escriboa-Carda et al., 2017). Nieves and Agust1 (2016) evaluated a large group of industries, in the field of biotechnology organizations and proposed that this could present some negative implications, considering the various features involved in providing high levels of human resources. These considerations lead one to conclude that there may be significant variations between various economic activities. The role of innovating in physical products and technology companies is usually allocated to one specific unit, such as research and improvement or product improvement (Waheed et al., 2019; Nieves and Agust1, 2016).

\section{HRM Practices and Service Innovation}

While innovation has historically been seen by science or technological experts, it is now understood that companies can rely on the perspectives, skills, and motives of employees to produce innovation (Shipton et al., 2017). Studies show that human-related factors help organizations improve service innovation behaviors and improve business performance (Alosani et al., 2020; Tajeddini et al., 2020). In other words, creativity results from workers' interactive activities. This view indicates that HRM determines the propensity of workers to work in that direction. Therefore, the paper proposed that when handled on the basis of HRM standards based on a community, internal human capital is optimized to promote creativity. Studies have shown empirically that HRM is the most important in achieving innovation (Tsou and Chen, 2020; AlMarzouqi, 2019; Nieves and Agust1, 2016). Research by Tsou and Chen, (2020) concluded that service creativity is positively affected by HRM activities. A company's success is measured by the ability to deal with different skills in its human resources, which is a fundamental factor in achieving high innovation rates and creating continuous new service innovations (Chang and Lee, 2020). The following hypothesis is hence proposed:

\section{H1. HRM activities have an impact on the innovation of services.}

\section{HRM Practices and Human Capital}

In the 21st century, "the most valuable corporate asset is seen by distinguished professors as the knowledge worker" (Macduffie, 1995). Human capital is the collection of skills, knowledge, social and personality characteristics, including creativity, embodied in the ability to perform labor in order to generate economic value (Becker, 1975). Accounting for management often deals with questions about how to model human beings as a capital asset. Human capital, however, broken down or defined, is vital for the success of an organization (Nieves and Agust1, 2016); human capital increases through education and experience. Recognizing the recruitment mode for human capital that contributes to the competitive advantage of the organization allows all HR-related managers to reconfigure, based on their potential, the entire current workforce. HRM practices that enhance the commitment of employees at all levels are shown to involve the development of 
human capital, but there are more chances of generating commitment through internal improvement. This shows that the most important consideration for increasing human capital is the effectiveness of HRM practices (Tsou and Chen, 2020; Ardito and Messeni, 2017). This discussion leads, therefore, to the following hypothesis:

H2. HRM practices have an impact on human capital.

\section{Human Capital and Service Innovation}

The definition of human capital relates to the expertise and skills of individuals that enable changes in behavior and economic growth (Becker, 1975). In order to do well in society, human resources can be built through structured training and education aimed at upgrading and renewing one's capabilities (Jawabreh et al., 2020). Previous researchers have differentiated between various forms of human capital (Chen and Huang, 2009). The literature, however, emphasizes human capital's primary function in creativity and success (Tsou and Chen, 2020). Research by Nieves and Agust1 (2016), for instance, concluded that human capital is a source of organizational creativity. This is in line with Nieves and Quintana's recent research (2016), which stated that human capital has a positive effect on the potential for organizational innovation. The integration of creativity into organizations' human capital and their management structure results in excellent efficiency (Nieves and Agustı, 2016; Chen and Huang, 2009). The unanimous consensus of successful management that creativity is one of the main factors for success, performance, and productivity (Rodríguez-Pose et al., 2020). It also positively impacts earnings, growth, and market shares of organizations (Ardito et al., 2017; Akbari and Monzavi, 2015) growth of jobs (Bonfanti et al., 2018; Chen and Peng, 2017); return on assets and growth of sales (Chang and Lee, 2020; Mulgan and Albury, 2003). Innovation is also pushing organizations to retain their strategic place and excellence in a turbulent and competitive world (Gaynor, 2002; LealRodríguez et al., 2015). In order to confront organizations with competitors, it is important to produce new goods, services, and processes (Carmeli and Schaubroeck, 2013). Effective innovation in services includes the development of adequate human resources in line with the organization's goals (Tajeddini et al., 2020). The following hypothesis is proposed:

H3. HRM practices has an impact on innovation in services.

\section{Mediating Role of Human Capital}

Providing theoretical support in the literature for human capital as a mediator. Previous research showed that several studies have used the mediation of human resources (Tsou and Chen, 2020; Chowhan, 2016; Nieves and Agust1, 2016). There is few research, however, that explores the relationships between HRM practices and innovation of services. This study, therefore, proposes, in the light of previous studies, that human capital acts as a mediating role between HRM activities and innovation in services. The following hypothesis is, therefore, proposed:

H4. The relationship between HRM practices and service innovation is mediated by human capital. Figure 1 presents the research model of the current study.

\section{METHODOLOGY}

This study seeks to demonstrate the relationship between human resource management practices and innovation in service in the hospitality sector, an area not well understood in the literature, as noted in the previous discussion. To conduct such a pilot study, which is based on the conceptual model described above, two basic steps were followed. First, reviewing the literature that dealt with the variables of this study, and then developing the study model and questionnaire. Second, the hypotheses of the model were tested via SEM, which in management studies was considered an acceptable process.

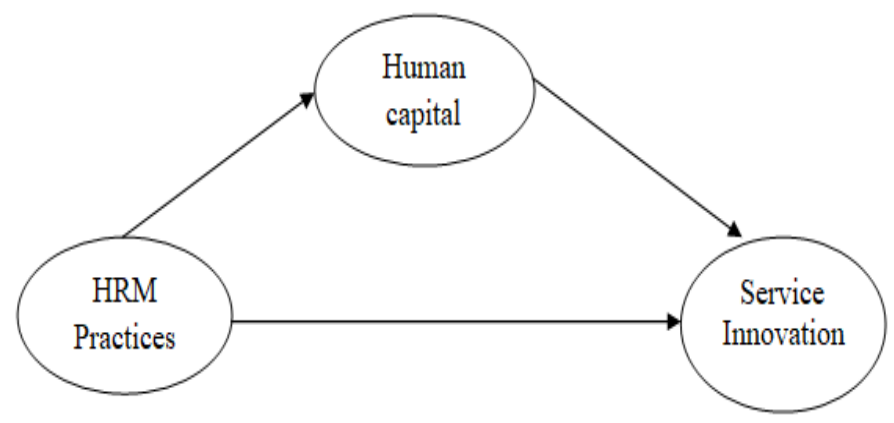

Table 1. Measurement of the study's variables

\begin{tabular}{|c|c|c|}
\hline Variable & $\begin{array}{c}\text { No. } \\
\text { of items }\end{array}$ & References \\
\hline $\begin{array}{c}\text { HRM } \\
\text { practices }\end{array}$ & 7 & $\begin{array}{c}\text { Alosani et al. (2020); } \\
\text { Andreassi et al. (2014); }\end{array}$ \\
\hline $\begin{array}{c}\text { Human } \\
\text { capital }\end{array}$ & 5 & $\begin{array}{c}\text { Madera et al. (2016); } \\
\text { Nieves and Agust (2016) }\end{array}$ \\
\hline $\begin{array}{c}\text { Service } \\
\text { innovation }\end{array}$ & 7 & $\begin{array}{c}\text { Gorochnaya et al., (2021); Alosani } \\
\text { et al. (2019); Chen et al. (2011), }\end{array}$ \\
\hline
\end{tabular}

Figure 1. Research model

\section{Research design and sample}

The data from this study was obtained from respondents once. A cross-sectional survey was, therefore, used. From December 2019 to February 2020, the survey was distributed among employees of the hospitality sector in Jordan. The convenient method of sampling was used to pick respondents in Jordan from the hospitality authorities. Despite the fact that the practical approach still lacks supporting studies that allow it to generalize its outcome (Okoe et al., 2018). Furthermore, SEM was used to evaluate the study data using the SmartPLS program.

\section{Measurement of variables and instrumentation}

The contingent and independent variables were, respectively, service creativity and HRM activities. As the mediating 
element, human capital was used. Numerous things extracted from previous studies were used to calculate the variables. In order to match the sample and local environment, these items were updated. In this research, a five-point Likert-scale used had possible responses ranging from "1" (strongly disagree) to "5" (strongly agree). Importantly, all variables were evaluated unidimensional and reflectively in this analysis. A unidimensional and reflective construct implies that there is a close relationship between the items measuring the constructs.

Deleting any of the objects during measurement model evaluations would not inherently impede their material validity when structures are evaluated unidimensional and reflectively (Hair et al., 2014). Given this result, with consideration of its dependent, independent, and mediating variables, the variables of this study are operationalized below. Table 1 displays the research variables and objects used for calculating them and their literature references.

\section{ANALYSIS}

The structural model was estimated using the SmartPLS program via the partial least square (PLS) path model. Earlier, the evaluation of the measured model is required in order to analyze the relationships between the different paths of the model (SanzValle et al., 2018; Barclay et al., 1995). This analysis is carried out in relation to the characteristics of individual item reliability, construct reliability, Extracted Average Variance (AVE), and the discriminant validity of the reflective scale indicators. The reliability of the measurement scales was checked by the Cronbach alpha coefficient and in all cases, a value greater than 0.7 was returned, which is considered acceptable in the literature. The composite reliability index was above the recommended threshold of 0.7, ranging from 0.955 to 0977 (Nunnally, 1978). The mean-variance extracted (AVE) ranged from 0.732 to 0.871 and showed that all reflective constructs exceeded the limit of 050 (Fornell and Larcker, 1981). The $\mathrm{R}^{2}$ value for the endogenous constructs, on the other hand, ranged from 0.465 to 0.605 and exceeded the recommended minimum value of 0.1 , which shows that the model is suitable for hypothesis testing (Table 3). It then assessed the discriminating validity of the reflective measures.

Table 2. Properties and correlations of the constructs

\begin{tabular}{|c|c|c|c|}
\hline Variable & HRM & \begin{tabular}{|l|} 
Human \\
Capital \\
\end{tabular} & $\begin{array}{c}\text { Service } \\
\text { Innovation }\end{array}$ \\
\hline HRM practices & 0.909 & & \\
\hline Human capital & 0.873 & 0.933 & \\
\hline Service innovation & 0.815 & 0.883 & 0.855 \\
\hline Mean & 4.029 & 3.767 & 4.130 \\
\hline SD & 0.683 & 0.540 & 0.628 \\
\hline AVE & 0.828 & 0.871 & 0.732 \\
\hline Cronbach's $\alpha$ & 0.955 & 0.965 & 0.977 \\
\hline $\mathrm{R}^{2}$ & 0.605 & 0.465 & 0.507 \\
\hline
\end{tabular}

Table 3. Results of direct hypothesis testing

\begin{tabular}{|l|c|c|c|c|}
\hline Hypothesis & $\beta$ & t-values & p-values & Supported \\
\hline H1. HRM $\longrightarrow$ Service innovation & 0.882 & 15.8 & 0.003 & Yes \\
\hline H2. HRM $\longrightarrow$ Human capital & 0.709 & 17.7 & 0.001 & Yes \\
\hline H3. Human capital $\longrightarrow$ Service innovation & 0.771 & 22.3 & 0.001 & Yes \\
\hline
\end{tabular}

Table 4. Results of indirect hypothesis testing

\begin{tabular}{cc|c|c|c|c}
\hline Hypothesis & $\beta$ & t-values & p-values & Supported \\
\hline H4. HRM $\longrightarrow$ Human capital $\longrightarrow$ Service innovation & 0.811 & 19.7 & 0.000 & Yes \\
\hline
\end{tabular}

Table 5. Results of the mediating role of human capital

\begin{tabular}{|c|c|c|c|c|c|c|c|}
\hline & & & & \multicolumn{4}{|c|}{ Indirect effect $95 \% \mathrm{CI}$} \\
\hline $\mathrm{H}$ & $\mathrm{a}$ & $\mathrm{b}$ & $\mathrm{C}^{\prime}$ & SE & Lower & Upper & Mediation role \\
\hline $\mathrm{H} 4$ & 0.689 & 0.695 & 0.761 & 0.054 & 0.756 & 0.884 & Partial \\
\hline
\end{tabular}

The values of the square of the mean-variance extracted for construction is greater than the corresponding correlations (see Table 2). Therefore, all factors had adequate discriminant validity. The model has good convergent validity, reliability, and discriminant validity in summary. The next move was to evaluate the hypothesized relationships in PLS-SEM route modeling. The route coefficient values and the bootstrapping results are shown in Table 3, which describes the direct hypothesized relationships between the study variables. All direct hypotheses are optimistic and are extremely necessary. The findings indicate that HRM has a positive and important influence on the service innovation of services $(\beta=0.882, \mathrm{t}=15.868, \mathrm{p}<$ $0.003)$ and on human resources $(\beta=0.709, \mathrm{t}=17.711, \mathrm{p}<0.001)$, thus promoting $\mathrm{H} 1$ and $\mathrm{H} 2$. Human capital has a positive and important effect on the innovation of services $(\beta=0.771, \mathrm{t}=22.322, \mathrm{p}<0.001)$, thus endorsing $\mathrm{H} 3$.

In line with Preacher and Hayes (2008) and suggested by Hair et al. (2014), and Hayes (2013) the bootstrapping approach is also used to assess the mediation effect. Specifically, in estimating the indirect effects, the bootstrapping approach with 5,000 samples and 95\% confidence intervals (CI) was used. The CI values of the indirect effect a*b are given by the PLS outputs. In addition, when a $95 \%$ CI excludes 0 , it is obvious that an indirect effect connects X and Y with $95 \%$ trust through the mediator. Table 4 reveals the bootstrapping results of the mediating effect of human capital on the relationship between HRM practices and service innovation. Table 5 presents that the confidence interval of the indirect effects of HRM practices on hospitality $(\beta=0.811, \mathrm{CI}=0.756$ to 0.884$)$ did not straddle a 0 . The direct path c' was significant and the signs of the paths a, b and c' were positive, indicating that human capital partially mediates (complimentary) the effect on the relationship between HRM practice and service innovation. Thus, the mediation effect of human capital on the relationship between HRM practices and service innovation was statistically significant $(b=0.811, t=19.7, \mathrm{p}<0.000)$, thereby supporting H4.

\section{DISCUSSION}

The aim of this study was to explore the relationship between human resource management and innovation in services and whether this relationship is mediated by human capital. In line with previous research (Tsou and Chen, 2020; Bonfanti et al., 2018; Gannon et al., 2015), this study found that there is a strong and positive association with service innovation to pursue high-performance HRM practices. Although this finding is interesting, the main contribution of this study to the literature is that it provides evidence supporting the idea that the positive relationship between human resource management and service innovation is mediated by human capital. While it has been suggested by some authors (Chang and Lee, 2020; 
Favoreu et al., 2019), research on this mediation is very scarce thus far (Buller and McEvoy, 2012; Mulgan and Albury, 2003). Second, this study also demonstrates that the policies and procedures that human resource management creates are a tool that can be used to inspire workers. In particular, according to the findings of this paper, human capital will benefit from adopting HR directives and strategies as service innovation or commitment-oriented framework by bringing together many of these activities that involve practices such as empowerment, continuous training, or motivation through the use of rewards for new ideas. In the context of this analysis, since human resource management practices are designed to enhance the service creativity of their departments, hostility also reduces the optimal use of human capital because the effect on innovation results in a weakness in the quality of the service provided and a negative impact on the internal customer which is reflected in his relationship with the customer. There is a strong correlation between human resource management and service innovation, and a positive relationship between human capital and service innovation.

The results of these articles go beyond contributions to the literature, but they also have important consequences for practitioners. One of the most important contributions made by this study is that it tells companies trying to encourage service innovation that engaging workers in creative work is an essential element in achieving this goal. This means that it is important for employees who are pursuing ways to reinforce exciting actions, reinvent existing concepts, discard old practices, and propose new ideas to implement those ideas. Also, when the degree of radicalization of inventions is greater, this form of human capital is more important (Chen, 2018). Current research shows common influences on service innovation for human resource management and human capital activities. In terms of the influence and role of human capital as a mediator in the relationship between human resource management activities and service innovation. The result of this study helps fill the void in the literature, especially in developing countries, and provides advice to service company owners in Jordan in particular on the alignment between human resource activities and human capital that It mediates the relationship between human resource management and innovation. It addresses the lack of studies that have examined human resource and human resource management practices as an approach to improving creativity in services.

There are some drawbacks to this analysis that need to be considered. The cross-sectional architecture of this research is first a limitation. Second, for all constructs, only subjective indicators were used, without using knowledge derived from other sources. Ultimately, data was obtained from the same respondent, the HRM director. While both of them usually participate in the board of management and are well educated about all the variables examined in this paper, it would have been more fitting to have responses from various managers. The limitations underlined in this paper must be resolved by future research. Longitudinal research, for example, could help to better understand the causal relationships between HRM, human capital, and innovation in services, and it would be useful to involve informants from various hotel levels. Furthermore, the analysis finds it important to look more closely into the relationships suggested by the inclusion of other variables in the model. In particular, the study suggests exploring how organizational learning influences HRM and SI relationships. In addition, the latest research by Waheed et al., (2019) shows that exploratory learning mediates the relationship between the understanding of HRM implementation by employees and their creativity in operation. This paper explores this relationship at the level of a person. Analyzing this connection at the organizational level will also be important, and in addition, the relationship between exploitative learning, HRM, and innovation in services is also examined. Finally, in an open innovation approach, another research line that can add to the literature is to review the model this paper proposes.

\section{CONCLUSION}

Qualified and trained human resources are the real assets of the company, and the human resources department must motivate and develop the skills and talents of employees. This study showed that there is a positive relationship between innovation and the high performance of human resources. Therefore, the success or failure of any service project depends on human capital, which is the link between the management of human resources and innovation in service.

Diverse human resource activities are the means to inspire and motivate workers. Empowerment, continuous training, and the use of rewards for new ideas also play a major role in preserving human capital and creating service. Therefore, modern human resources departments realize that the satisfaction of the internal customer (the employee) leads to the satisfaction of the external customer (the customer). Providing the appropriate internal environment is the responsibility of human resources management, and it is an environment for innovation and creativity in service provision.

\section{REFERENCES}

Akbari, A.A., \& Monzavi, M.R. (2015). The study of the effects of knowledge management on innovation and organisational performance: a case study in small and medium enterprises in Qom. European Online Journal of Natural and Social Sciences, 4( 1), 677-686.

AlMarzouqi, S. (2019). The organisational capabilities and their effects on service innovation and service innovation process in the UAE public sector. International Journal of Management and Commerce Innovations, 7 (1), 124-140.

Alosani, M.S., Al-Dhaafri, H.S., \& Abdulla, A.A. (2020). Investigating the role of HRM practices on service innovation: empirical evidence from UAE government agencies. Management Research Review, 44 (1), 1-24. https://doi.org/10.1108/MRR-03-2020-0141

Alosani, M.S., Yusoff, R., \& Al-Dhaafri, H. (2019). The effect of innovation and strategic planning on enhancing organizational performance of Dubai Police. Innovation \& Management Review, 17 (1), 2-24. https://doi.org/10.1108/INMR-06-2018-0039

Anderson, N., Potočnik, P., \& Zhou. J. (2014). Innovation and creativity in organizations: a state-of-thescience review. Journal of Management Studies, 40 (5), 1297-1333. https://doi.org/10.1177/0149206314527128

Ardito, L., \& Messeni, P.A. (2017). Breadth of external knowledge sourcing and product innovation: The moderating role of strategic human resource practices. European Management Journal, 35 (2), 261-272. http://dx.doi.org/10.1016/j.emj.2017.01.005

Bamber, G.J., Bartram, T., \& Stanton, P. (2017). HRM and workplace innovations: formulating questions. Personnel Research, 46 (7), 12161227. https://doi.org/10.1108/PR-10-2017-0292 
Barclay, D., Thompson, R., \& Higgins, C. (1995). The Partial Least Squares (PLS) approach to causal modeling: personal computer adoption and use as an illustration. Technology Studies, 2(2), 285-309.

Battistelli, A., Montani, F., Odoardi, C., Vandenberghe, C., \& Picci, P. (2014). Employees' concerns about change and commitment to change among Italian organizations: the moderating role of innovative work behavior. The International Journal of Human, Resource Management, 25 (7), 951-978. https://doi.org/10.1080/09585192.2013.809012

Bazazo, I.K., \& Alananzeh, O.A. (2020). The implementation of international standards and specifications (ISO-SCUBA) on improving the quality of Diving tourism in Aqaba, Jordan. GeoJournal of Tourism and Geosites, 33(4), 1557-1563. https://doi.org/10.30892/gtg.334spl17-608

Becker, G.S. (1975). Human capital. Chicago: University of Chicago Press.

Bonfanti, A., Del Giudice, M., \& Papa, A. (2018). Italian craft firms between digital manufacturing, open innovation, and servitization. Journal of the Knowledge Economy, 9 (1), 136-149. https://doi.org/10.1007/s13132-015-0325-9

Booyens, I., \& Rogerson, C. (2016). Unpacking the geography of tourism innovation in Western Cape Province, South Africa. Bulletin of Geography: SocioEconomic Series, 31, 19-36. https://doi.org/10.1515/bog-2016-0002

Boxal, P., Purcell, J., \& Wright, P.M. (2007). The Oxford Handbook of Human Resource Management, Oxford University Press on Demand. https://doi.org/10.1093/oxfordhb/9780199547029.001.0001

Buller, P., \& McEvoy, G. (2012). Strategy, human resource management and performance: sharpening line of sight. Human Resource Management Review, 22 (1), 43-56. https://doi.org/10.1016/j.hrmr.2011.11.002

Carmeli, A., \& Schaubroeck, J. (2013). How leveraging human resource capital with its competitive distinctiveness enhances the performance of commercial and public organizations. Human Resource Management. 44(4),391-412. https://doi.org/10.1002/hrm.20081

Chang, J.I., \& Lee, C.Y. (2020). The effect of service innovation on customer behavioral intention in the Taiwanese insurance sector: the role of word of mouth and corporate social responsibility. Journal of Asia Business Studies, 14 (3), 341-360. https://doi.org/10.1108/JABS-06-2018-0168

Chang, S., Gong, Y., \& Shumb, C. (2011). Promoting innovation in hospitality companies through human resource management practices. International Journal of Hospitality Management, 30, 812- 818. https://doi.org/10.1016/j.ijhm.2011.01.001

Chen, Z. (2018). Job satisfaction among frontline police officers in China: the role of demographic, work-related, organisational and social factors. Psychology, Crime and Law, 24 (9), 895-914. https://doi.org/10.1080/1068316X.2018.1442835

Chen, D., \& Peng, X. (2017). Research on the relationship between transformational leadership and government service innovation. Open Journal of Leadership, 6 (2), 82-94. https://doi.org/10.4236/oj1.2017.62005

Chen, J.C., \& Huang, W.J. (2009). Strategic human resource practices and innovation performance-the mediating role of knowledge management capacity. Journal of Business Research, 62 (1), 104-114. https://doi.org/10.1016/j.jbusres.2007.11.016

Chivandi, A., \& Maziriri, E.T. (2018). Modeling relationships between innovation antecedents and service innovation: A Zimbabwean hotel managers perspectives. GeoJournal of Tourism and Geosites, 23(3), 633-643. https://doi.org/10.30892/gtg.23301-315

Chowhan, J. (2016). Unpacking the black box: understanding the relationship between strategy, HRM practices, innovation and organisational performance. Human Resource Management Journal, 26 (2), 112-133. https://doi.org/10.1111/1748-8583.12097

De Dreu, C.K.W., Baas, M., \& Nijstad, B.A. (2008). Hedonic tone and activation level in the mood-creativity link: Toward a dual pathway to creativity model. Journal of Personality and Social Psychology, 94(5), 739-756. https://doi.org/10.1037/0022-3514.94.5.739

Deeb, A., Alananzeh, O., Masa'deh, R., \& Tarhini, A. (2020). Factors Affecting Job Performance: The Case of Jordanian Hotels' Kitchen Staff. International Journal of Public Sector Performance Management, 6 (3), 340-360. https://doi.org/10.1504/IJPSPM.2020.107766

Ebersberger, B., Herstad, S.J., \& Nordli, A. (2021). Hospitality innovation strategies: Robustness analysis of paths to firm performance. Tourism Management, 85. https://doi.org/10.1016/j.tourman.2021.104310

Elsharnouby, T.H., \& Elbanna, S. (2021). Change or perish: Examining the role of human capital and dynamic marketing capabilities in the hospitality sector. Tourism Management, 82. https://doi.org/10.1016/j.tourman.2020.104184

Engelman, R.M., Fracasso, E.M., Schmidt, S., \& Zen, A.C. (2017). Intellectual capital, absorptive capacity and product innovation. Management Decision, 55 (3), 474-490. https://doi.org/10.1108/MD-05-2016-0315

Escriboa-Carda, N., Balbastre-Benavent, F., \& Canet-Giner, M.T. (2017). Employees' perceptions of high-performance work systems and innovative behaviour: the role of exploratory learning. European Management Journal, 35 (2), 273-281. https://doi.org/10.1016/ d.emj.2016.11.002

Favoreu, C., Maurel, C., Carassus, D., \& Marin, P. (2019). Influence and Complementarity of Follow-on Managerial Innovations within a Public Organization. Public Organiz Rev 19, 345-365 . https://doi.org/10.1007/s11115-018-0411-0

Fornell, C., \& Larcker, D.F. (1981). Evaluating structural equation models with unobservable variables and measurement error. Journal of Marketing Research, 18 (1), 39-50. https://doi.org/10.2307/3151312

Gannon, J.M., Roper, A., \& Doherty, L. (2015). Strategic human resource management: insights from the international hotel industry. International Journal of Hospitality Management, 47, 65-75. https://doi.org/10.1016/j.ijhm.2015.03.003

Ganzer, P.P., Chais, C., \& Olea, P.M. (2017). Product, process, marketing and organizational innovation in industries of the flat knitting sector. RAI Revista de Administração e Inovação, 14 (4), 321-332. https://doi.org/10.1016/j.rai.2017.07.002

Gorochnaya, V., Mikhaylov, A., Plotnikova, A., \& Mikhaylova, A. (2021). The interdependence bewteen turism innovation activity in the western borderlands of Russia. GeoJournal of Tourism and Geosites, 34(1), 147-154. https://doi.org/10.30892/gtg.34119-630

Hair, J., Hult, G., Tomas, M., Ringle, C., \& Sarstedt, M. (2014). A Primer on Partial Least Squares Structural Equation Modeling. Sage Publications, ISBN: 9781483377445.

Hayes, A.F. (2013). Introduction to Mediation, Moderation, and Conditional Process Analysis: A Regression-Based Approach, Guiford Press. ISBN 9781462534654.

Jaiswal, N.K. \& Dhar, R.L. (2015). Transformational leadership, innovation climate, creative self-efficacy and employee creativity: A multilevel study. International Journal of Hospitality Management, 51, 30-41. https://doi.org/10.1016/j.ijhm.2015.07.002

Jawabreh, O., Masa'deh, R., Mahmoud, R., \& Hamasha, S.A. (2020). Factors influencing the employees service performance in hospitality industry case study Aqaba five star hotel. GeoJournal of Tourism and Geosites, 29(2), 649-661. https://doi.org/10.30892/gtg.29221-496

Knies, E., \& Leisink, P. (2018). People management in the public sector, in HRM in Mission Driven Organisations. Palgrave Macmillan, Cham, 15-46, ISBN 978-3-319-57583-4.

Kozioł-Nadolna, K. (2020). The Role of a Leader in Stimulating Innovation in an Organization. Administrative Science 10 (59). https://doi.org/10.3390/admsci10030059

Kraśnicka, T., Głód, W., \& Wronka-Pośpiech, M. (2018). Management innovation, pro-innovation organisational culture and enterprise performance: testing the mediation effect. Review of Managerial Science, 12 (3), 737-769. https://doi.org/10.1007/s11846-017-0229-0 
Lepak, D., \& Snell, S.A. (2002). Examining the human resources architecture: The relations among human capital, employment, and human resources configurations. Journal of Management, 28(4), 517-543. https://doi.org/10.1177/014920630202800403

Ling, F.Y.Y., Ning, Y., Chang, Y.H. and Zhang, Z. (2018). Human resource management practices to improve project managers' job satisfaction. Engineering, Construction and Architectural Management, 25 (5), 654-669. https://doi.org/10.1108/ECAM-02-2017-0030

Liu, D., Gong, Y., Zhou, J., \& Huang, J. (2017). Human resource systems, employee creativity, and firm innovation: the moderating role of firm ownership. Academy of Management Journal, 60 (3), 1164-1188. https://doi.org/10.5465/amj.2015.0230

Losey, M.R. (1999). Mastering the competencies of HR management. Human Resource Management, 38 (2), 99-102. https://doi.org/10. 1002/(SICI)1099-050X(199922)38:2<99::AID-HRM3>3.0.CO;2-T

Macduffie, J.P. (1995). Human resource bundles and manufacturing performance: Organizational logic and flexible production systems in the world auto industry. Industrial and Labor Relations Review, 48, 197-221. https://doi.org/10.2307/2524483

Madera, J., Dawson, M., Guchait, P., \& Belarmino, A. (2017). Strategic human resources management research in hospitality and tourism: A review of current literature and suggestions for the future. International Journal of Contemporary Hospitality Management, $29,48-67$. https://doi.org/10.1108/IJCHM-02-2016-0051

Mulgan, G., \& Albury, D. (2003). Innovation in the public sector. London: Innovation in the Public Sector, Strategy Unit, Cabinet Office.

Nieves, J., \& Agust1, Q. (2016). Human resource practices and innovation in the hotel industry: The mediating roleof human capital. Tourism and Hospitality Research, 8(5), 215-225. https://doi.org/10.1177/1467358415624137

Nunnally, J.C. (1978). Psychometric theory (2nd ed.). New York: McGraw-Hill.

Okoe, A.F., Boateng, H., Narteh, B., \& Boakye, R.O. (2017). Examining human resource practice outcomes and service innovation. The Service Industries Journal, 38 (7/8), 431-445. https://doi.org/10.1080/02642069.2017.1397636

Porter, M.E., \& Stern, S. (2001). Innovation: location matters, MIT Sloan Management Review, 42 (4), 28-36.

Preacher, K.J., \& Hayes, A.F. (2008). Asymptotic and resampling strategies for assessing and comparing indirect effects inmultiplemediatormodels. Behavior Research Methods, 40 (3), 879-891. https://doi.org/10.3758/brm.40.3.879

Reynoso, J., Kandampully, J., Fan, X. \& Paulose, H. (2015). Learning from socially-driven service innovation in emerging economies. Journal of Service Management, 26 (1), 156-176. https://doi.org/10.1108/JOSM-11-2013-0313

Rodríguez-Pose, A., \& Zhang, M. (2020). The cost of weak institutions for innovation in China. Technological Forecasting and Social Change, Elsevier, 153(C). https://doi.org/10.1016/j.techfore.2020.119937

Salem, I.E. (2014). Toward better understanding of knowledge management: Correlation to hotel performance and innovation in five-star chain hotels in Egypt. Tourism and Hospitality Research, 14(4), 176-196. https://doi.org/10.1177/1467358414542265

Salunke, S., Weerawardena, J., \& McColl-Kennedy, J.R. (2013). Competing through service innovation: The role of bricolage and entrepreneurship in project-oriented firms. Journal of Business Research, 66(8), 1085-1097. https://doi.org/10.1016/j.jbusres.2012.03.005

Sanz-Valle, R., \& Jiménez-Jiménez, D. (2018). HRM and product innovation: does innovative work behavior mediate that relationship? Management Decision, 56 ( 6), 1417-1429. https://doi.org/10.1108/MD-04-2017-0404

Shipton, H., Sparrow, P., Budhwar, P., \& Brown, A. (2017). HRM and innovation: looking acrosslevels. Human Resource Management Journal, 27 (2), 246-263. https://doi.org/10.1111/1748-8583.12102

Stojcic, S., Srhoj, S., \& Alex, C. (2020). Innovation procurement as capability-building: evaluating innovation policies in eight central and Eastern European countries. European Economic Review, 121, 103-330. https://doi.org/10.1016/j.euroecorev.2019.103330

Subramaniam, M., \& Youndt, M.A. (2005). The influence of intellectual capital on the types of innovative capabilities. Academy of Management Journal, 48(3), 450-463. https://doi.org/10.5465 / AMJ.2005.17407911

Tajeddini, K., Martin, E., \& Altinay, L. (2020). The importance of human-related factors on service innovation and performance. International Journal of Hospitality Management, 85, 1-14. https://doi.org/10.1016/j.ijhm.2019.102431

Trusova, N.V., Cherniavska, T.A., Pasieka, S.R., Hranovska, V.Hr., Prystemskyi, O.S., \& Demko, V.S. (2020). Innovative clustering of the region in the context of increasing competitive positions of the enterprises of the tourist-recreational destination. GeoJournal of Tourism and Geosites, 31(3), 1126-1134. https://doi.org/10.30892/gtg.31326-549

Tsou, H.T., \& Chen, J.S. (2020). Dynamic capabilities, human capital and service innovation: the case of Taiwan ICT industry. Asian Journal of Technology Innovation, 28(2), 181-203. https://doi.org/10.1080/19761597.2020.1719852

Waheed, A., Miao, X., Waheed, S., Ahmad, N., \& Majeed, A. (2019). How new HRM practices, organisational innovation, and innovative climate affect the innovation performance in the IT industry: a moderated-mediation analysis. Sustainability, 11(3), 1-21. https://doi.org/10.3390/su11030621

Wright, P.M., Mccormick, B., Sherman, W.S., \& Mcmahan, G.C. (1999). The role of human resource practices in petro-chemical refinery performance. The International Journal of Human Resource Management, 10 (4), 551-571. https://doi.org/10.1080/095851999340260

Yamao, S., Cieri, H.D., \& Hutchings, K. (2009). Transferring subsidiary knowledge to global headquarters: Subsidiary senior executives' perceptions of the role of HR configurations in the development of knowledge stocks. Human Resource Management, 48(4), 531-554. https://doi.org/10.1002/hrm.20297

Yang, C., \& Lin, C.Y. (2009). Does intellectual capital mediate the relationship between HRM and organizational performance? Perspective of a healthcare industry in Taiwan. The International Journal of Human Resource Management, 20(9), 1965-1984. https://doi.org/10.1080/09585190903142415

\footnotetext{
Article history: Received: 14.02.2021 Revised: 19.04.2021 Accepted: 24.05.2021 Available online: 15.06 .2021
} 